\title{
Mental Health Effects Of Biomarkers In Chronic Renal Failure: Stress And Alexithymia Dimention
}

\author{
Esra Tayaz ( $\nabla$ esratayaz@gmail.com ) \\ Ankara Yildirim Beyazit Universitesi https://orcid.org/0000-0001-6614-8401 \\ Ayşegül Koç \\ Ankara Yildirim Beyazit Universitesi
}

\section{Research article}

Keywords: alexithymia, biomarkers, hemodialysis, nursing, chronic renal failure, stress

Posted Date: August 28th, 2019

DOI: https://doi.org/10.21203/rs.2.13666/v1

License: (9) This work is licensed under a Creative Commons Attribution 4.0 International License. Read Full License

Version of Record: A version of this preprint was published at Yonago Acta Medica on January 1st, 2019. See the published version at https://doi.org/10.33160/yam.2019.11.005. 


\section{Abstract}

Background: Chronic renal failure causes many physical problems in patients. Hemodialysis treatment and the stress that accompanies the treatment are high and this constitutes a basis for alexithymia. Changes in biomarkers cause physical symptoms and increase individuals' stress levels. Methods: The sample for the researcher was completed with 72 individuals. Demographic data form, biochemical data form, Hemodialysis Stressor Scale, and Toronto Alexithymia Scale were used in this study. Results: Individuals participating in the study found that the perceived stress levels were high in all dimensions and $59.7 \%$ were alexithymic. The relationship between Toronto alexithmia scale and hemodialysis stressor scale and the selected biomarkers was determined $(p<0.05)$. Conclusion: It was concluded that stress and alexithymic feelings were high among hemodialysis patients and it was suggested the awareness of health professionals and patients should be increased in areas of coping with stress and emotional management in hemodialysis treatment patients.

\section{Background}

Chronic Renal Failure (CRF) affects many physically challenged patients, as does the psychological and social aspects of hemodialysis (HD) treatment and adherence due to mechanical intervention brought by the patient. In addition, patients with CRF who receive HD treatment for several reasons including the shrinking of their habitat, the deterioration of their quality of life, fear of death, role changes, and loss of work power, are a group that should be carefully considered due to these variables [1]. The most common renal replacement treatment (RRT) method in our country is hemodialysis. More than $90 \%$ end-of-stage renal disease (ESRD) patients have three HD treatment sessions per week [2].

The normal life pattern of patients with ESRD who are on HD treatment is significantly impaired [3]. Individuals with ESRD have high levels of stress due to medical treatment, diet treatment, and HD treatment, particularly in physical and psychological problems that occur during the uremic period $[3,4]$. In individuals who undergo hemodialysis treatment, stressors prepare the alexithymic background in proportion to the disease's duration [5]. Alexithymic behaviors associated with HD treatment were defined as nervousness, irritability, loss of interest and desire, loss of hope for the future, distress, anxiety, and resultant emotional deprivation $[5,6]$. Alexithymic individuals lose the convincing qualities of feelings such as fear, anger, sadness, and can cause individuals to mask their emotions [7].

HD treatment causes fluid electrolyte imbalances. The most important of these causes is known as a change in biomarkers and accompanying symptoms [8]. There are cardiovascular symptoms such as sodium and water retention, renin-angiotensinaldosterone system activation-induced hypertension (HT), congestive heart failure (CHF) as a result of excess fluid accumulation, and gode-releasing edema. Symptoms such as itching, cognitive process disorders, ulceration, ecchymosis, purpura, gastrointestinal system (GIS) nausea, vomiting, mouth ammonia odor, hemorrhage as a result of urea elevation in the saliva, and intra-oral ulcerations are seen as the result of metabolic waste and cannot be removed from the kidneys; metabolic acidosis and urea elevation result in neurological problems in patients. These problems cause problems such as lassitude, fatigue, confusion, behavioral changes, and agitation $[8,9,10]$.

A multidimensional holistic approach should be adopted while performing nursing care activities in the process of CRF and $\mathrm{HD}$ treatment. It is not appropriate to address symptom management or psychosocial dimension alone in the nursing approach of CRF [11].

Senturk et al. (2000) reported that middle-aged depression was present among CRF patients who received HD treatment and that more than half were alexithymic [5]. A study by Pop-Jordanova and Polenakovic (2014) emphasized that alexithymia was higher in patients receiving HD treatment than in other groups compared with those who had alexithymia in half of the HD patients without sex differences and among healthy individuals and cancer patients [12]. In a study conducted by Kojima et al. (2007), HD patients were found to be susceptible to depression and alexithymic [13].

It was thought that nurses working as caregivers for CRF patients with HD treatment in our study would be able to assess the relationship between the biomarkers, stress levels, and alexithymia of patients and thus develop holistic care and develop guidelines for this disease. This study was carried out to evaluate the relationship between selected biomarkers for patients receiving $\mathrm{HD}$ treatment and stress and alexithymia.

Page 2/13 


\section{Methods}

\subsection{Study design}

The prospective cross-sectional demographic data of our study were designed to assess the relationship between biochemical data, hemodialysis stressors and alexithymia.

\subsection{Participants}

This study was carried out at a Research Hospital nephrology policlinic, Emergency Hemodialysis Unit, and Hemodialysis unit in Turkey, although HD patients who needed HD treatment in internal and surgical clinics were not registered. Therefore, sampling was completed with $72 \mathrm{HD}$ patients. Criteria for inclusion in the survey were:

- Taking HD treatment for six months or over due to CRF diagnosis.

- Eighteen years of age or older, reading the informed consent form and agreeing to participate in the work.

$\cdot$ Literate.

Exclusion criteria in the research were:

- Other than HD, serious cognitive problems, psychiatric diagnosis or tumor and metastasis.

- Receiving HD treatment unless for CRF diagnosis.

- Having HD treatment with a CRF diagnosis for less than six months

- Cannot speak Turkish.

\subsection{Measures and instruments}

\subsubsection{Patients' demographic characteristics}

The data collection form as prepared by the researcher in relation to the HD treatment to determine the patients' demographic data was used in this research. This form included 11 questions, including patients' socio-demographic data, how many medications they took, HD acquisition time, age, gender, additional chronic disease status, education status, marital status, income level, occupation and working status.

\subsubsection{Biochemical data form}

A biochemical data form was used to collect biochemical data. Formal urea, creatinine, hemogram, hematocrit, albumin, sodium, potassium, and $\mathrm{C}$ reactive protein values were noted.

\subsubsection{Hemodialysis stressor scale (HSS)}

Hemodialysis Stressor Scale was used to determine stress.

Hemodialysis Stressor Scale (HSS): The scale was developed by Baldree et al. and was adapted to Turkish society by Kara [14]. The HSS is a five-point Likert-type scale and is coded as "always" 5, "often" 4, "sometimes" 3, "rarely" 2 and "never" 1. HSS has been identified in HD patients as physical (HSS-1) and psychosocial stressors (HSS-2) and the markers of physical stressors were indicated with six $(2,3,7,10,11,20)$ questions. Questionnaires for psychosocial stressors were determined with $23(1,4,5,6,8,9$, $12,13,14,15,16,17,18,19,21,22,23,24,25,26,27,28,29)$ items [14]. The physical hemodialysis stressor score is $6-30$ and the psychosocial hemodialysis stressor score is $23-115$ points. The total score of HSS varies in 29-145 points. The total HSS score ranges 29-145 and increasing the score on the scale indicates that the perceived stress level is higher [14]. The hemodialysis Stressor Scale Cronbach's a value 0.77, item total score correlation coefficients $(r) 0.22-0.49(p<0.0001)$ (excluding item 1: $r=0.12$, $\mathrm{p}=0.02$ ) were reported in the scale's validity and reliability study [15]. 


\subsubsection{Toronto alexithymia scale (TAS-20)}

The Toronto Alexithymia Scale was used to measure alexithymia.

Toronto Alexithymia Scale (TAS-20): A self-report scale consisting of 20 items evaluating alexithymia, with a score of 1-5, likerttype and three subscales. These sub-dimensions are:

1. Difficulty identifying feelings (TAS-1) $(1,3,6,7,9,13,14)$ : Difficulty identifying feelings and distinguishing them from the physical senses that accompany emotional stimulation.

2. Difficulty expressing emotions (TAS-2) $(2,4,11,12,17)$ : Difficulty transferring emotions to others.

3. Outward-thinking (TAS-3) $(5,8,10,15,16,18,19,20)$ : The existence of an outward cognitive structure is explained as aweakness of inward thinking and imagination.

Individuals are asked to mark the most appropriate score for each item from "Never", "Rarely", "Sometimes", "Often" and "Always". High scores indicate a high alexithymic level. This scale was developed by Bagby et al. (1994) and Turkish adaptation was done by Gulec et al. (2009). Items 4, 5, 10, 18 and 19 on the scale are scored in reverse [16]; the cut-off value of TAS-20 is 51 and less, with 52-60 indicating possible alexithymia and a score $>61$ indicating alexithymia [17].

\subsection{Data collection and procedure}

This research was carried out between 03.08.2016 and 04.04.2017. The single measurement biochemical values of the participants who participated in the study planning were examined. The biochemical values were measured immediately before taking hemodialysis treatment and evaluations were done in this direction. Verbal information was given prior to the application, confirmed by filling informed consent forms, and approved on the basis of volunteerism. The questionnaire forms were coded face-to-face by the researcher, with the patient name, initials and admission numbers to avoid duplicate questionnaires.

\subsection{Analysis}

The distribution of continuous variables such as age, albumin, and CRP in the study were examined by Shapiro-Wilk test and normality graphs. All continuous measures were expressed as mean \pm standard deviation (median $\pm s$ ), the median number of daily medications used (min-max), and categorical variables as numbers.

The consistency of responses to HSS and TAS-20 was assessed with Cronbach's a. Subgroups of HSS, TAS-20, and scales were tested by Mann-Whitney $U$ test and independent sample tests according to gender and additional chronic illness status, KruskalWallis test, and one-way ANOVA according to marital status and hemodialysis time. Relationships between scale scores, biochemical laboratory results, and the number of drugs used daily were examined by Pearson or Spearman Correlation analyses depending on the distribution of variables. The statistical significance level was accepted as $p<0.05$. The Cronbach's a value of HSS

in our study was 0.789 and the Cronbach's a value for TAS- 20 was measured as 0.737 . Accordingly, the consistency of responses to the scale was acceptable $(0.70<a<0.80)$.

\section{Results}

The following findings were obtained in the data obtained from our study. Additional chronic diseases of patients with CRF with hemodialysis treatment were hypertension in $50 \%$, diabetes mellitus in $23.6 \%$, and other chronic diseases in $19.4 \%$ (Figure 1).

When the alexithymia levels of subjects participating in the study were examined, it was found that $59.7 \%(n=43)$ were alexithymic (Table 1). 
55.6\% $(n=40)$ were men, 66.7\% $(n=48)$ were married, and 63.9\% $(n=46)$ had additional chronic diseases. Hemodialysis durations were $30.6 \%(n=22)$ for six months to two years, $27.7 \%(n=20)$ for $2-5$ years, $15.3 \%(n=10)$ for $5-8$ years, $8.3 \%(n=6)$ for $8-10$ years, and $18.1 \%(\mathrm{n}=13)$ for $>10$ years. (Table 2$)$. The relationship between the subscales of demographic data, HSS, HSS subscales, TAS20, and TAS-20 subscales was evaluated in Table 2. Additional chronic disease and the HSS-1 subscale were statistically significant.

The biomarkers of urea, creatinine, hemoglobin, hematocrit, albumin, sodium, potassium, calcium, phosphorus, and C-reactive protein (CRP) values of the subjects who participate in the study were evaluated. The median number of medications used by the patients on a daily basis was three (min-max: 1-20). Normally deviating values were determined and the relationship between the HSS, HSS subscales, TAS-20, and TAS-20 subscale scores was assessed. A positive correlation was found between the TAS-20 point average and the HSS-1, between the HSS score average and TAS-1, between CRP and HSS, HSS-2 and the number of drugs used daily and HSS-1 in the direction of the obtained results. There was a negative correlation between creatinine and HSS-1, TAS20, TAS-2, TAS-3, between hemoglobin and TAS-1, between hematocrit and TAS-1, between sodium and HSS-1, between potassium and TAS-3 (Table 3).

\section{Discussion}

Additional chronic illnesses cause physical and psychological disadvantages in HD-treatment recipients. In a study in which hemodialysis patients were followed for a long period $(n=9,333)$, the presence of comorbid chronic illness affected the HD course, $60 \%$ of patients $(n=5,404)$ had chronic vascular disease history and $30 \%$ and $60 \%$ reported using antihypertensive drugs [18]. Mollaoglu and Bag (2009) reported that $68.8 \%(n=86)$ of individuals treated with HD were accompanied by a chronic disease. In a study conducted by Sagduyu et al., 35.3\% of HD patients had another chronic illness [19], Ozturk et al. (2009) conducted a study and found $27 \%$ of chronic illnesses of individuals had CRF in addition to HD with HT, $18.4 \%$ had diabetes mellitus (DM), and $14.2 \%$ had other systemic diseases [20]. In our study, more than half of the sampled individuals had chronic illness $(n=46)$. Of our sample with chronic disease, half were diagnosed with hypertension, $23.6 \%$ with DM, and the remaining $19.4 \%$ with other systemic diseases (Figure 1).

When Pop-Jordanova\&Polenakovic evaluated HD patients in Macedonia $(n=230)$ with TAS-20, $50 \%$ of subjects reported alexithymic appearance [12]. When the literature is examined, there was a linear relationship between alexithymic symptoms and the increase in the hemodialysis treatment duration. Sinatra et al. (2011) found that patients who received HD treatment for four years or longer were alexithymic as a primary psychiatric appearance accompanying depression [21]. The duration of HD treatment in our study was not significantly different from the literature; approximately half of those participating in the study were found to have alexithymia (Table 1). For individuals who were receiving chronic hemodialysis treatment, emotional disorders, time, diet and functional limitations, self-identity change and fear of death were quite high in addition to induced exhaustion. Meanwhile, we may think that the concept of alexithymia is influenced by culture.

Davison and Jhangri (2005) found that $31.5 \%(n=64)$ of 205 hemodialysis patients received nine months or less of advanced HD treatment, 32.5\% $(n=66)$ received treatment for 9-24 months, and 36.0\% $(n=73)$ received 24 months of long-duration HD treatment. In a different study, HD patients had a mean HD treatment duration of $58.75 \pm 48.94$ months [22, 23]. In our study, 22 patients $(30.6 \%)$ were treated for six months to two years, 20 patients $(27.7 \%)$ for $2-5$ years, 11 patients $(15.3 \%)$ for $5-8$ years, six patients $(8.3 \%)$ for $8-10$ years and 13 patients $(18.1 \%)$ had hemodialysis for $>10$ years (Table 2 ). Exposure to the physical and psychological variables with which hemodialysis patients have to cope when the treatment duration increases is directly proportional to the duration. This process should be followed carefully in terms of patients and healthcare workers; our findings are similar to the literature.

In the course of hemodialysis treatment, physiological changes such as edema and ultrafiltration may make individuals' biomarkers unstable. Griva et al. found that the hemoglobin value was lower in HD treatment [24]. According to a systematic review, statistical significance was reported according to quality of life and sub-dimensions in health in three studies in which CRP value was evaluated in HD patients [25]. The biomarkers of Kalender et al. were evaluated according to the HD treatment of two or three sessions per week. In the study hemoglobin, hematocrit, albumin and calcium levels were found to be higher in HD patients with

Page 5/13 
three sessions per week and urea, creatinine, potassium and phosphorus values in HD patients with two sessions. Therefore, threeweek HD treatment patients had higher treatment efficacy than two-session patients [26]. When studies evaluating hemodialysis patients were examined, it was evident that biomarkers have multidimensional effects on patient health. These parameters are thought to increase patients' HD-induced stress and provide abasis for the alexithymic appearance.

When we evaluated the variables with HSS and HSS subscales, we found no relationship between gender, marital status, hemodialysis duration, attendant chronic disease variables, scale, and scale subscales $(p>0.05)$. There was statistically significance between the presence of accompanying chronic illness and the HSS physical subscale mean scores $(t=3.394, p=0.001)$. Shahrokhi et al. (2014) reported no significant relationship between the type of HD-related stressor, sex, marital status, education, number of HD sessions per week, and HD duration in hemodialysis patients [27]. Mok\&Tam (2001) found similar results [28]. In a similar study conducted by Ahmad\&Nazly (2015), they reported that as the duration of HD increased, the attitude of coping with stress and seeking social support entered a negative relationship. In the same study, they reported that the difference between HSS and the HSS physical and psychosocial subscale was statistically significant when hemodialysis treatment was examined according to the gender variable [29]. Most physical stressors included fatigue, fluid restriction, nutritional limitations, and difficulties in dressing due to venous catheterization. Most psychosocial stressors can be considered as time loss, location problems, transportation, sleep disturbances, addiction and suffering. Meanwhile, issues of parental role change with children, isolation and transfer problems can be included. This is the result of these variables affecting HD induced stress.

Patients' scores on the Toronto alexithymia scale and subscales were compared with gender, marital status, comorbid chronic illness status and hemodialysis duration (Table 2). The mean TAS-20 score of female patients was $62.19 \pm 9.49$ and that of males was $62.67 \pm 10.22$. TAS-20 scores were similar between genders $(t=0.208, p=0.836)$. When the scores of TAS-20 subgroups were examined in terms of gender, it was determined that the mean scores were similar and that gender was not related to alexithymia $(p>0.05)$. According to marital status, the mean TAS-20 point average and sub-dimensions were not statistically significant ( $p>0.05$ ). Pistorio et al. (2017) found that the difference was significant when patients with physical and somatic complaints with patients undergoing kidney transplantation exhibited a more alexithymic appearance. In the same study, they reported that no linkage when comparing by gender [30]. Pop-Jordanova\&Polenakovic (2014) found a linear relationship between age and alexithymia. Furthermore, alexithymic appearance was found to be relatively high in males when evaluated according to gender. When assessed by factor analysis according to TAS-20 subscales, TAS-1 and TAS-2 age and duration of hemodialysis were not significant, whereas the TAS-3 outward-thinking subscale was significant [12]. As reported in a study conducted in Japan, individuals with ESRD treatment were classified into two groups according to their depression scores and their alexithymic appearances were examined. It has been reported that individuals with high depression scores have high alexithymic appearances. In this study, there was a negative correlation between the duration of hemodialysis and alexithymic appearance [13]. In ESRD and $\mathrm{HD}$ treatment, the physical stress caused by fluid changes leads to psychosomatic complaints, which in turn affect psychological appearance when treatment duration is prolonged. In addition, comorbid chronic illnesses and other psychiatric manifestations may increase the appearance of alexithymia when an individual expresses emotional distress. The individual in the alexithymic view has difficulty managing the treatment process, and their physical condition may also deteriorate.

The biochemical results of the scores obtained from the physical and psychosocial dimensions of HSS and the HSS of hemodialysis patients and correlation analysis with the number of drugs used each day were analyzed (Table 3). Harwood et al. (2009) found that biomarkers in CRF patients were directly related to stress and coping strategies and were statistically significant. Hemoglobin and albumin were statistically significant in these parameters but urea and creatinine parameters were not affected by stress [31]. Individuals' biochemical changes can be interpreted as their experiencing difficulty coping with stress because they affect their levels of fatigue. Hemodialysis patients may also be informed about psychosocial variables in addition to the presession biochemical subjects' potential physical status. Nurses should also have knowledge of various blood parameters in the dialysis process; this evaluation will increase nursing patients' quality of care and positively affect patient comfort.

The correlation between the scores of hemodialysis patients with TAS-20 and its subscales, the biochemical results, and the number of medications used were evaluated and the relationship between them was evaluated (Table 3). Lai et al. (2017) found an inverse correlation between biological markers and alexithymic appearance with phosphorus, hemoglobin levels, and psychological status directly in renal failure patients grouped according to treatment modalities. In the same study, patients' potassium, calcium, phosphorus, hemoglobin values, and emotional levels were evaluated and found to be statistically significant [32]. Calia et al. 
(2015) evaluated patients' emotional state and alexithymia; they were compared with creatinine and blood urea nitrogen (BUN) levels by physiological parameters and there was no statistical significance with physiological parameters in the appearance of alexithymia. According to a self-assessment scale related to negative emotional control, only a negative relationship was found between creatinine and the negative emotional control [33].

A patient's metabolic activities, blood circulation, physiological variables and psychological state may vary in the course of dialysis due to renal failure. Whatever CRF method is used, it leads to stress and fatigue in the body to adapt to sudden changes in metabolites at the end of treatment; the mood changes. Therefore, it is important that records are periodically evaluated including the biochemical data of these group patients who are followed up clinically and at home and that this is reflected in nursing care plans. The disease, treatment process, biochemical findings, and psychosocial status are very important in terms of reflecting a patient's present condition. It is also an important indicator of the quality of nursing care in reducing complications and fluidinduced stress, such as in other chronic diseases, improving compliance, planning, improving diet and treatment regimen, and improving comfort.

\section{Conclusions}

The biomarkers of patients undergoing HD treatment were evaluated in terms of hemodialysis stress and alexithymia. Hemoglobin, hematocrit, sodium, albumin and calcium values were found low in urea, creatinine, potassium, phosphorus and CRP values of selected patients in HD treatment. The stress levels of the patients were high and more than half of the patients $(n=43)$ were found to have alexithymia; it was concluded that there is a relationship between the additional chronic disease condition and the HSS physical sub-dimension. There was also a relationship between HSS and CRP, between the HSS physical subscale and TAS-20, creatinine, sodium, and the number of daily medications, the HSS psychosocial sub-dimension and CRP. There is also an association between TAS-20 and creatinine, between TAS- 1 and HSS, between hemoglobin and hematocrit, between TAS-2 and creatinine, and between TAS-3, creatinine, and potassium in HD-treated subjects. The observed results are compatible with the literature.

In future studies, it is suggested that the drugs used should be examined based on their generic names and drug characteristics. Multiple measurements and repetitions can be planned to determine the fluctuations and their effects; this is suggested to increase awareness of the importance of coping with stress, managing emotions, high stress and the lack of emotion in communication skills with individuals.

Our study has limitations. Drug factors in our study include that non-generic names have been evaluated, a single center has been evaluated, the number of sessions was not examined as a variable, and only pre-HD measurements were used.

\section{Abbreviations}

CRF: Chronic Renal Failure

HD: Hemodialysis

RRT: Renal replacement treatment

ESRD: End-of-stage renal disease

HT: Hypertension

CHF: Congestive heart failure

GIS: Gastrointestinal system

HSS: Hemodialysis Stressor Scale

HSS-1: Physical stressors

HSS-2: Psychosocial stressors 
TAS-20: Toronto Alexithymia Scale

TAS-1: Difficulty identifying feelings

TAS-2: Difficulty expressing emotions

TAS-3: Outward-thinking

CRP: C-reactive protein

DM: Diabetes mellitus

BUN: Blood urea nitrogen

\section{Declarations}

\section{Ethics approval and consent to participate}

The Ethics Committee required for this research was the Ethics Committee of the a university Institute of Humanities and Social Sciences in Turkey (decision number 351 dated 02.08.2016). Afterward, the institution was granted permission from the a Research Hospital ethics committee in Turkey where the research was conducted and the clinical chiefs were informed (decision number 1181 dated 28.09.2016). Volunteer consent was obtained in writing from the people who participated in the study. The study is based on voluntary participation.

\section{Consent to publish}

The study was not published in another journal or congress.

\section{Funding}

No funding was provided.

\section{Competing interests}

There is no conflict of interest between the authors.

\section{Availability of data and materials}

The data of the study will be shared if requested.

\section{Authors' Contributions}

Author contributions are as follows and all authors approved the final version for submission.

Identifying, designing, and collecting the main idea of the work-E.T., A.K.,

Writing of the article, Critical revision, Analysis and interpretation of the data-E.T., A.K.,

Interpretation of the data and translation-E.T., A.K.

Critical revision, Analysis and interpretation of the data-E.T.

Writing of the article, Critical revision, Analysis and interpretation of the data-E.T.

\section{Acknowledgements}

Acknowledgements are not applicable. 


\section{References}

1. Ozdemir, U., Tascl, S., 2013. Psychosocial Problems And Care Of Chronic Diseases. Erciyes University Medical Science Journal. 1(1), 57-72. http://sbfe-dergi.erciyes.edu.tr/article/view/1051000090

2. Ates, K., Suleymanlar, G., Seyahi, N., 2015. In Turkey Nephrology, Dialysis and Transplantation-Registry 2014. Ankara: TC. Ministry of Health and Turkish Nephrology Association. 1-89. http://www.nefroloji.org.tr/folders/file/2014-REGISTRYKITABI.pdf

3. Sezer, M. T., 1997. Psychiatric Issues. Hemodialysis Physician Handbook, Istanbul: Turkish Nephrology Society Publication. 147-152.

4. Kara, B., 2007. Adherence to treatment in hemodialysis patients: a multiple-aspect approach. Gulhane Medical Journal. 49, 132136. http://gulhanemedj.org/uploads/pdf/pdf_GMJ_364.pdf

5. Senturk, A., Levent, B. A., Tamam, L., 2000. The Psychopathology in Patients with Chronic Renal Failure Treated with Hemodialysis. Ondokuz Mayıs University Medical Journal. 17(3), 163-172. https://dergipark.org.tr/download/articlefile/189259

6. Sasıoglu, M., Gulol, C., Tosun, A., 2013. The Concept of Alexithymia. Current Approaches in Psychiatry. 5(4), 507-527. http://www.psikguncel.org/archives/vol5/no4/cap_05_31.pdf

7. Kauhanen, J., Kaplan, G. A., Julkunen, J., Wilson, T. W., Salonen, J. T., 1993. Social Factors in Alexithymia. Comprehensive Psychiatry. 34(5), 330-335. http://dx.doi.org/10.1016/0010-440X(93)90019-Z

8. Akdemir, N., Birol, L., 2011. Internal Medicine and Nursing Care. Ankara: System Offset. 578-606.

9. Ovayolu, N., Ovayolu, O., 2016. Basic Internal Medicine Nursing and Chronic Diseases with Different Dimensions. Cukurova Nobel Medical Bookstores. 1, 350-390.

10. Karabulutlu, E. Y., Okanli, A., 2011. The Evaluation of Illness Perceptions in Hemodialysis Patients. Journal of Anatolia Nursing and Health Sciences. 14(4), 25-31. http://e-dergi.atauni.edu.tr/ataunihem/article/view/1025006640/1025006529

11. Axelsson, L., Alvariza, A., Lindberg, J., Öhlén, J., Håkanson, C., Reimertz, H., ... \& Årestedt, K. (2018). Unmet palliative care needs among patients with end-stage kidney disease: a national registry study about the last week of life. Journal of pain and symptom management, 55(2), 236-244. https://doi.org/10.1016/j.jpainsymman.2017.09.015

12. Pop-Jordanova, N., Polenakovic, M., 2014. Alexithymia Construct in Dialysis Patients. Bantao Journal. 12(1), 45-51. http://dx.doi.org/10.2478/bj-2014-0010

13. Kojima, M., Hayano, J., Tokudome, S., Suzuki, S., Ibuki, K., Tomizawa, H., et al., 2007. Independent Associations of Alexitimia and Social Support with Depression in Hemodialysis Patients. Journal of Psychosomatic Research. 63, 349-356. https://www.sciencedirect.com/science/article/abs/pii/S0022399907001535?via\%3Dihub

14. Kara, B., 2006. Validity and Reliability Study of the Hemodialysis Stressor Scale. Journal of Health Education Research, Zonguldak Health College. 2(2), 64-71. (Control number: 3387540)

15. Kara, B., Iscan, B., 2006. Nurses' Perceived Stressors in Hemodialysis Patients. Journal of Nephrology Nursing. 57-64.

16. Gulec, H., Kose, S., Gulec, M., Citak, S., Evren, C., Borckardt, J., et al., 2009. Reliability and Factorial Validity of the Turkish Version 20-item Toronto Alexithymia Scale (TAS-20). Bulletin of Clinical Psychopharmacology. 19(3), 214-220. http://pcp.psikofarmakoloji.org/pdf/TR/19_3_2.pdf

17. Salbas E. Ftronline. 2016. Ftronline website. www.ftronline.com/toronto-aleksitimi-olcegi/. Last access: 20 Mayıs 2017.

18. Hannedouche, T., Roth, H., Krummel, T., London, G. M., Jean, G., Bouchet, J.-L., et al., 2016. Multiphasic Effects of Blood Pressure on Survival in Hemodialysis Patients. Kidney International. 90, 674-684. http://dx.doi.org/10.1016/j.kint.2016.05.025

19. Mollaoglu, M., Bag, E., 2009. Related Factors and the Self- Efficacy in Patients Undergoing Hemodialysis. Journal of Istanbul Faculty of Medicine. 72(2), 37-42. https://dergipark.org.tr/download/article-file/98321

20. Ozturk, A., Atuntas, Y., Ozsan, M., Gunduz, E., 2009. Investigation of the Knowledge, Attitudes, Behaviors of Chronic Renal Failure Patients Treated by Hemodialysis on Their illness and Hemodialysis. Erciyes Medical Journal. 31(2), 119-125. https://www.cabdirect.org/cabdirect/abstract/20093164259

21. Sinatra, M., Curci, A., Palo, V. D., Monacis, L., Tanucci, G., 2011. How Dialysis Patients Live: A Study on Their Depression and Associated Factors in Southern Italy. Scientific Research. 2(9), 969-977. http://dx.doi.org/10.4236/psych.2011.29146

Page 9/13 
22. Davison, S. N., Jhangri, G. S., 2005. The Impact of Chronic Pain on Depression, Sleep, and the Desire to Withdraw from Dialysis in Hemodialysis Patients. Journal of Pain and Symptom Management. 30(5), 465-473.

http://dx.doi.org/10.1016/j.jpainsymman.2005.05.013

23. Demir, B., Okanli, A., 2013. The Determination of Relaxation Exercises Effect on Anger and Anger Control in Hemodialysis Patients. Journal of Anatolia Nursing and Health Sciences. 16(4), 227-233. http://edergi.atauni.edu.tr/ataunihem/article/view/1025008426

24. Griva, K., Davenport, A., Harrison, M., Newman, S., 2010. An Evaluation of Illness, Treatment Perceptions, and Depression in Hospital-vs. Home-based Dialysis Modalities. Journal of Psychosomatic Research. 69, 363-370. http://dx.doi.org/10.1016/j.jpsychores.2010.04.008

25. Spiegel, B. M., Melmed, G., Robbins, S., Esrailian, E., 2008. Biomarkers and Health-Related Quality of Life in End-Stage Renal Disease: A Systematic Review. Clinical Journal of the American Society of Nephrology. 3, 1759-1768. http://dx.doi.org/10.2215/CJN.00820208

26. Kalender, B., Erdogan, M. S., Sengul, E., Serdengecti, K., Erek, E., Yilmaz, A., 2002. The Relationship Between Nutritional Status and Adequacy of Dialysis in Hemodialysis Patients. Cerrahpaşa J Med. 33(4), 223-230.

http://www.ctf.edu.tr/dergi/online/2002v33/s4/024a4.pdf

27. Shahrokhi, Z., Rayyani, M., Sabzevari, S., Haghdoost, A. A., 2014. Stressors and Coping Strategies in Dialysis Patients. Iranian Journal of Critical Care Nursing. 7(3), 184-193. https://pdfs.semanticscholar.org/3da0/d2ed91f95570abbafe34ed642ad0ab969c79.pdf

28. Mok, E., Tam, B., 2001. Stressors and Coping Methods Among Chronic Haemodialysis Patients in Hong Kong. Journal of Clinical Nursing. 10, 503-511. http://dx.doi.org/10.1046/j.1365-2702.2001.00500.x

29. Ahmad, M. M., Nazly, E. K., 2015. Hemodialysis: Stressors and Coping Strategies. Psychology, Health \& Medicine. 20(4), 477487. http://dx.doi.org/10.1080/13548506.2014.952239

30. Pistorio, M., Veroux, M., Sinagra, N., Basile, G., Pasquale, C. D., 2017. Alexithymia in Kidney Transplantation Patients. Transplantation Proceedings. 49, 642-645. http://dx.doi.org/10.1016/j.transproceed.2017.02.031

31. Harwood, L., Wilson, B., Locking-Cusolito, H., Sontrop, J., Spittal, J., 2009. Stressors and Coping in Individuals with Chronic Kidney Disease. Nephrology Nursing Journal. 36(3), 265-277. https://www.ncbi.nlm.nih.gov/pubmed/19588694

32. Lai, C., Aceto, P., Luciani, M., Fazzari, E., Cesari, V., Luciano, S., et al., 2017. Emotional management and biological markers of dietetic regimen in chronic kidney disease patients. Renal Failure. 39(1), 173-178.

http://dx.doi.org/10.1080/0886022X.2016.1256312

33. Calia, R., Lai, C., Aceto, P., Luciani, M., Camardese, G., Lai, S., et al., 2015. Emotional Self-Efficacy and Alexithymia May Affect Compliance, Renal Function and Quality of Life in Kidney Transplant Recipients: Results from a Preliminary Cross-Sectional Study. Physiology \& Behavior. 142, 152-154. http://dx.doi.org/10.1016/j.physbeh.2015.02.018

\section{Tables}

Table 1. Percentage distributions according to alexithymia levels of hemodialysis patients $(\mathrm{n}=72)$

\begin{tabular}{|l|r|r|}
\hline & Sample (n) & Percent (\%) \\
\hline No alexithymia (51 points and below) & 10 & 13.9 \\
\hline Possible alexithymia (52-60 points) & 19 & 26.4 \\
\hline Alexithymia (61 points and above) & 43 & 59.7 \\
\hline
\end{tabular}

Table 2. Demographic data rates of individuals who received hemodialysis treatment, evaluation of demographic data with HSS, HSS subscales, TAS-20, TAS-20 subscales 


\begin{tabular}{|c|c|c|c|c|c|c|c|c|c|}
\hline Charateristics & Categories & $\begin{array}{l}\mathrm{n}(\%) \\
\overline{\mathrm{x}} \pm \mathrm{SD}\end{array}$ & $\begin{array}{l}\text { HSS } \\
\overline{\mathrm{x}} \pm \text { SD } \\
\mathrm{Z}(\mathrm{t}) / \chi^{2}(\mathrm{f}) ; \\
\mathrm{p}\end{array}$ & $\begin{array}{l}\text { HSS-1 } \\
\bar{x} \pm S D \\
Z(t) / \chi^{2} \\
\text { (f); } p\end{array}$ & $\begin{array}{l}\text { HSS-2 } \\
\overline{\mathrm{x}} \pm \text { SD } \\
\mathrm{Z}(\mathrm{t}) / \chi^{2}(\mathrm{f}) \\
\mathrm{p}\end{array}$ & $\begin{array}{l}\text { TAS } \\
\bar{x} \pm S D \\
Z(t) / \chi 2(f) \\
p\end{array}$ & $\begin{array}{l}\text { TAS-1 } \\
\bar{x} \pm S D \\
Z(t) / \chi^{2} \\
(f) ; p\end{array}$ & $\begin{array}{l}\text { TAS-2 } \\
\bar{x} \pm S D \\
Z(t) / \chi^{2} \\
(f) ; p\end{array}$ & $\begin{array}{l}\text { TAS-3 } \\
\bar{x} \pm S D \\
Z(t) / \chi^{2} \\
(f) ; p\end{array}$ \\
\hline Gender & $\begin{array}{l}\text { Female } \\
\text { Male }\end{array}$ & $\begin{array}{l}32 \\
(44.4) \\
40 \\
(55.6)\end{array}$ & $\begin{array}{l}88.94 \pm 10.86 \\
86.90 \pm 15.52 \\
0.578 ; 0.563\end{array}$ & $\begin{array}{l}19.03 \pm 3.93 \\
17.47 \pm 4.21 \\
1.606 ; \\
0.113\end{array}$ & $\begin{array}{c}69.91 \pm 9.99 \\
69.42 \pm 13.50 \\
0.168 ; 0.867\end{array}$ & $\begin{array}{c}62.19 \pm 9.49 \\
62.67 \pm 10.22 \\
0.208 ; 0.836\end{array}$ & $\begin{array}{c}20.34 \pm 3.93 \\
20.35 \pm 4.71 \\
0.473 ; \\
0.636\end{array}$ & $\begin{array}{c}14.81 \pm 3.30 \\
14.62 \pm 4.05 \\
0.212 \\
0.833\end{array}$ & $\begin{array}{c}27.03 \pm 4.95 \\
27.70 \pm 4.55 \\
0.545 ; \\
0.586\end{array}$ \\
\hline Marital status & $\begin{array}{l}\text { Married } \\
\text { Single } \\
\text { Divorced }\end{array}$ & $\begin{array}{l}48 \\
(66.7) \\
14 \\
(19.4) \\
10 \\
(13.9)\end{array}$ & $\begin{array}{l}88.21 \pm 14.81 \\
87.93 \pm 11.51 \\
85.70 \pm 10.71 \\
0.828 ; 0.661\end{array}$ & $\begin{array}{l}18.40 \pm 4.17 \\
18.29 \pm 4.08 \\
16.90 \pm 4.22 \\
0.732 ; \\
0.694\end{array}$ & $\begin{array}{l}69.81 \pm 13.21 \\
69.64 \pm 9.52 \\
68.80 \pm 9.51 \\
0.029 ; 0.972\end{array}$ & $\begin{array}{c}60.73 \pm 9.08 \\
64.29 \pm 11.34 \\
68.20 \pm 9.47 \\
2.824 ; 0.066\end{array}$ & $\begin{array}{c}20.00 \pm 4.64 \\
20.64 \pm 3.52 \\
21.60 \pm 4.09 \\
2.795 ; \\
0.247\end{array}$ & $\begin{array}{c}14.19 \pm 3.56 \\
15.07 \pm 4.06 \\
16.70 \pm 3.53 \\
2.040 \\
0.138\end{array}$ & $\begin{array}{c}26.54 \pm 4.55 \\
28.57 \pm 5.32 \\
29.90 \pm 3.60 \\
5.870 \\
0.053\end{array}$ \\
\hline $\begin{array}{l}\text { Chronic } \\
\text { disease }\end{array}$ & $\begin{array}{l}\text { Yes } \\
\text { No }\end{array}$ & $\begin{array}{l}46 \\
(63.9) \\
26 \\
(26.1)\end{array}$ & $\begin{array}{l}88.67 \pm 11.32 \\
86.27 \pm 17.04 \\
0.205 ; 0.837\end{array}$ & $\begin{array}{l}19.33 \pm 3.52 \\
11.12 \pm 4.39 \\
3.394 ; \\
0.001\end{array}$ & $\begin{array}{l}69.35 \pm 10.35 \\
70.15 \pm 14.66 \\
0.272 ; 0.786\end{array}$ & $\begin{array}{c}64.15 \pm 8.78 \\
59.46 \pm 11.02 \\
1.983 ; 0.051\end{array}$ & $\begin{array}{c}21.04 \pm 4.11 \\
19.12 \pm 4.56 \\
1.325 \\
0.185\end{array}$ & $\begin{array}{c}14.93 \pm 3.60 \\
14.31 \pm 3.94 \\
0.686 \\
0.495\end{array}$ & $\begin{array}{c}28.17 \pm 4.44 \\
26.04 \pm 4.94 \\
1.651 ; \\
0.099\end{array}$ \\
\hline $\begin{array}{l}\text { Duration of } \\
\text { hemodialysis }\end{array}$ & $\begin{array}{l}\text { 6month-2year } \\
2-5 \text { year } \\
5-8 \text { year } \\
8 \text { - } 10 \text { year } \\
\text { 10year\&more }\end{array}$ & $\begin{array}{l}22 \\
(30.6) \\
20 \\
(27.7) \\
11 \\
(15.3) \\
6 \\
(8.3) \\
13 \\
(18.1)\end{array}$ & $\begin{array}{l}89.64 \pm 18.96 \\
88.85 \pm 10.83 \\
82.18 \pm 8.64 \\
83.50 \pm 3.94 \\
89.85 \pm 12.61 \\
6.844 ; 0.144\end{array}$ & $\begin{array}{l}18.41 \pm 4.74 \\
19.05 \pm 3.24 \\
16.27 \pm 3.32 \\
15.67 \pm 4.41 \\
19.15 \pm 4.36 \\
6.544 ; \\
0.162\end{array}$ & $\begin{array}{l}71.23 \pm 16.43 \\
69.80 \pm 9.79 \\
65.91 \pm 8.38 \\
67.83 \pm 6.49 \\
70.69 \pm 11.41 \\
2.343 ; 0.673\end{array}$ & $\begin{array}{c}62.45 \pm 11.38 \\
63.50 \pm 7.82 \\
61.45 \pm 10.44 \\
65.17 \pm 9.66 \\
60.46 \pm 10.42 \\
0.320 ; 0.864\end{array}$ & $\begin{array}{c}21.27 \pm 5.70 \\
20.00 \pm 3.91 \\
20.00 \pm 3.03 \\
21.67 \pm 2.34 \\
19.00 \pm 4.04 \\
3.847 \\
0.427\end{array}$ & $\begin{array}{c}14.45 \pm 4.28 \\
15.10 \pm 3.14 \\
14.18 \pm 3.34 \\
15.50 \pm 4.23 \\
14.62 \pm 3.99 \\
0.872 ; \\
0.929\end{array}$ & $\begin{array}{c}26.73 \pm 4.94 \\
28.40 \pm 3.63 \\
27.27 \pm 5.98 \\
28.00 \pm 4.60 \\
26.85 \pm 5.10 \\
\\
1.239 ; \\
0.872\end{array}$ \\
\hline
\end{tabular}

Table 3. Assessment of the relationship between biochemical parameters, total score average of TAS-20, total mean score of HSS and the number of daily medicines used by HSS, HSS subscales, TAS-20, TAS-20 subscales 


\begin{tabular}{|c|c|c|c|c|c|c|c|c|c|}
\hline Biomarkers & $\overline{\mathrm{x}} \pm \mathrm{SD}(\mathrm{n}=72)$ & & HSS & HSS-1 & HSS-2 & TAS & TAS-1 & TAS-2 & TAS-3 \\
\hline TAS-20 & $62.46 \pm 9.84$ & \begin{tabular}{|l} 
Correlation \\
coefficient \\
$\mathrm{p}$ \\
\end{tabular} & $\begin{array}{l}0.081 \\
0.500\end{array}$ & $\begin{array}{l}0.241 \\
0.042\end{array}$ & $\begin{array}{l}0.034 \\
0.774\end{array}$ & - & - & - & - \\
\hline HSS & $87.81 \pm 13.59$ & \begin{tabular}{|l} 
Correlation \\
coefficient \\
$\mathrm{p}$ \\
\end{tabular} & - & - & - & $\begin{array}{l}0.081 \\
0.500\end{array}$ & $\begin{array}{l}0.251 \\
0.033\end{array}$ & $\begin{array}{l}0.140 \\
0.242\end{array}$ & $\begin{array}{c}-0.162 \\
0.174\end{array}$ \\
\hline Urea & $131.47 \pm 30.45$ & \begin{tabular}{|l} 
Correlation \\
coefficient \\
$\mathrm{p}$ \\
\end{tabular} & $\begin{array}{l}-0.003 \\
0.982\end{array}$ & $\begin{array}{c}-0.137^{*} \\
0.250\end{array}$ & $\begin{array}{c}-0.009 * \\
0.939\end{array}$ & $\begin{array}{c}-0.120^{*} \\
0.316\end{array}$ & $\begin{array}{l}0.021 \\
0.861\end{array}$ & $\begin{array}{c}-0.117 * \\
0.329\end{array}$ & $\begin{array}{l}-0.121 \\
0.310\end{array}$ \\
\hline Creatinine & $8.34 \pm 2.57$ & \begin{tabular}{|l} 
Correlation \\
coefficient \\
$\mathrm{p}$ \\
\end{tabular} & $\begin{array}{l}-0.073 \\
0.542\end{array}$ & $\begin{array}{c}-0.285^{*} \\
0.015\end{array}$ & $\begin{array}{c}-0.112 * \\
0.349\end{array}$ & $\begin{array}{c}-0.337 * \\
\mathbf{0 . 0 0 4}\end{array}$ & $\begin{array}{l}-0.203 \\
0.088\end{array}$ & $\begin{array}{c}-0.309 * \\
\mathbf{0 . 0 0 8}\end{array}$ & $\begin{array}{l}-0.251 \\
0.033\end{array}$ \\
\hline Hemoglobin & $11.47 \pm 1.66$ & $\begin{array}{l}\text { Correlation } \\
\text { coefficient } \\
\mathrm{p} \\
\end{array}$ & $\begin{array}{c}-0.118 \\
0.322\end{array}$ & $\begin{array}{c}0.089^{*} \\
0.458\end{array}$ & $\begin{array}{c}0.050^{*} \\
0.675\end{array}$ & $\begin{array}{c}-0.071^{*} \\
0.556\end{array}$ & $\begin{array}{l}-0.277 \\
\mathbf{0 . 0 1 8}\end{array}$ & $\begin{array}{c}0.072^{*} \\
0.550\end{array}$ & $\begin{array}{l}-0.104 \\
0.386\end{array}$ \\
\hline Hematocrit & $34.00 \pm 4.99$ & $\begin{array}{l}\text { Correlation } \\
\text { coefficient } \\
\mathrm{p} \\
\end{array}$ & $\begin{array}{l}-0.108 \\
0.368\end{array}$ & $\begin{array}{c}0.060^{*} \\
0.619\end{array}$ & $\begin{array}{c}-0.031 * \\
0.798\end{array}$ & $\begin{array}{c}-0.065^{*} \\
0.589\end{array}$ & $\begin{array}{r}-0.281 \\
0.017\end{array}$ & $\begin{array}{c}0.094^{*} \\
0.431\end{array}$ & $\begin{array}{l}-0.137 \\
0.252\end{array}$ \\
\hline Albumin & $3.58 \pm 0.58$ & $\begin{array}{l}\text { Correlation } \\
\text { coefficient } \\
\mathrm{p} \\
\end{array}$ & $\begin{array}{l}-0.155 \\
0.201\end{array}$ & $\begin{array}{c}-0.133 \\
0.271\end{array}$ & $\begin{array}{l}-0.139 \\
0.253\end{array}$ & $\begin{array}{l}-0.120 \\
0.324\end{array}$ & $\begin{array}{c}-0.189 \\
0.117\end{array}$ & $\begin{array}{l}0.058 \\
0.633\end{array}$ & $\begin{array}{l}-0.191 \\
0.112\end{array}$ \\
\hline Sodium & $135.56 \pm 2.99$ & \begin{tabular}{|l} 
Correlation \\
coefficient \\
$\mathrm{p}$ \\
\end{tabular} & $\begin{array}{r}-0.076 \\
0.526\end{array}$ & $\begin{array}{l}-0.236 \\
\mathbf{0 . 0 4 6}\end{array}$ & $\begin{array}{l}0.008 \\
0.950\end{array}$ & $\begin{array}{l}0.037 \\
0.755\end{array}$ & $\begin{array}{l}-0.027 \\
0.825\end{array}$ & $\begin{array}{l}0.101 \\
0.398\end{array}$ & $\begin{array}{l}0.024 \\
0.839\end{array}$ \\
\hline Potassium & $5.23 \pm 0.71$ & $\begin{array}{l}\text { Correlation } \\
\text { coefficient } \\
\mathrm{p} \\
\end{array}$ & $\begin{array}{l}0.050 \\
0.676\end{array}$ & $\begin{array}{c}-0.016^{*} \\
0.894\end{array}$ & $\begin{array}{c}0.062^{*} \\
0.608\end{array}$ & $\begin{array}{c}-0.197^{*} \\
0.098\end{array}$ & $\begin{array}{l}0.025 \\
0.837\end{array}$ & $\begin{array}{c}-0.071^{*} \\
0.556\end{array}$ & $\begin{array}{l}-0.283 \\
\mathbf{0 . 0 1 6}\end{array}$ \\
\hline Calcium & $8.79 \pm 0.84$ & \begin{tabular}{|l} 
Correlation \\
coefficient \\
$\mathrm{p}$ \\
\end{tabular} & $\begin{array}{l}0.126 \\
0.295\end{array}$ & $\begin{array}{c}0.027 * \\
0.821\end{array}$ & $\begin{array}{c}0.098^{*} \\
0.417\end{array}$ & $\begin{array}{c}0.036^{*} \\
0.745\end{array}$ & $\begin{array}{l}0.134 \\
0.265\end{array}$ & $\begin{array}{c}-0.032 * \\
0.788\end{array}$ & $\begin{array}{l}-0.095 \\
0.429\end{array}$ \\
\hline Phosphorus & $5.34 \pm 1.37$ & $\begin{array}{l}\text { Correlation } \\
\text { coefficient } \\
\mathrm{p} \\
\end{array}$ & $\begin{array}{l}0.130 \\
0.291\end{array}$ & $\begin{array}{c}-0.038^{*} \\
0.761\end{array}$ & $\begin{array}{c}0.162^{*} \\
0.186\end{array}$ & $\begin{array}{c}-0.048^{*} \\
0.699\end{array}$ & $\begin{array}{l}0.018 \\
0.884\end{array}$ & $\begin{array}{c}-0.033^{*} \\
0.791\end{array}$ & $\begin{array}{l}-0.093 \\
0.449\end{array}$ \\
\hline C-reactive protein & $15.15 \pm 19.64$ & $\begin{array}{l}\text { Correlation } \\
\text { coefficient } \\
\mathrm{p} \\
\end{array}$ & $\begin{array}{l}0.385 \\
0.015\end{array}$ & $\begin{array}{l}0.148 \\
0.370\end{array}$ & $\begin{array}{l}0.322 \\
\mathbf{0 . 0 4 6}\end{array}$ & $\begin{array}{l}-0.081 \\
0.623\end{array}$ & $\begin{array}{l}0.135 \\
0.412\end{array}$ & $\begin{array}{l}-0.018 \\
0.912\end{array}$ & $\begin{array}{l}-0.163 \\
0.321\end{array}$ \\
\hline $\begin{array}{l}\text { Number of medications } \\
\text { used daily }\end{array}$ & $\begin{array}{l}\text { Median } 3 \text { (min-maks: } \\
1-20)\end{array}$ & $\begin{array}{l}\text { Correlation } \\
\text { coefficient } \\
\mathrm{p}\end{array}$ & $\begin{array}{l}0.110 \\
0.358\end{array}$ & $\begin{array}{l}0.266 \\
\mathbf{0 . 0 2 4}\end{array}$ & $\begin{array}{l}-0.006 \\
0.957\end{array}$ & $\begin{array}{l}0.037 \\
0.758\end{array}$ & $\begin{array}{l}0.002 \\
0.984\end{array}$ & $\begin{array}{l}0.032 \\
0.791\end{array}$ & $\begin{array}{c}-0.009 \\
0.941\end{array}$ \\
\hline
\end{tabular}

Figures 


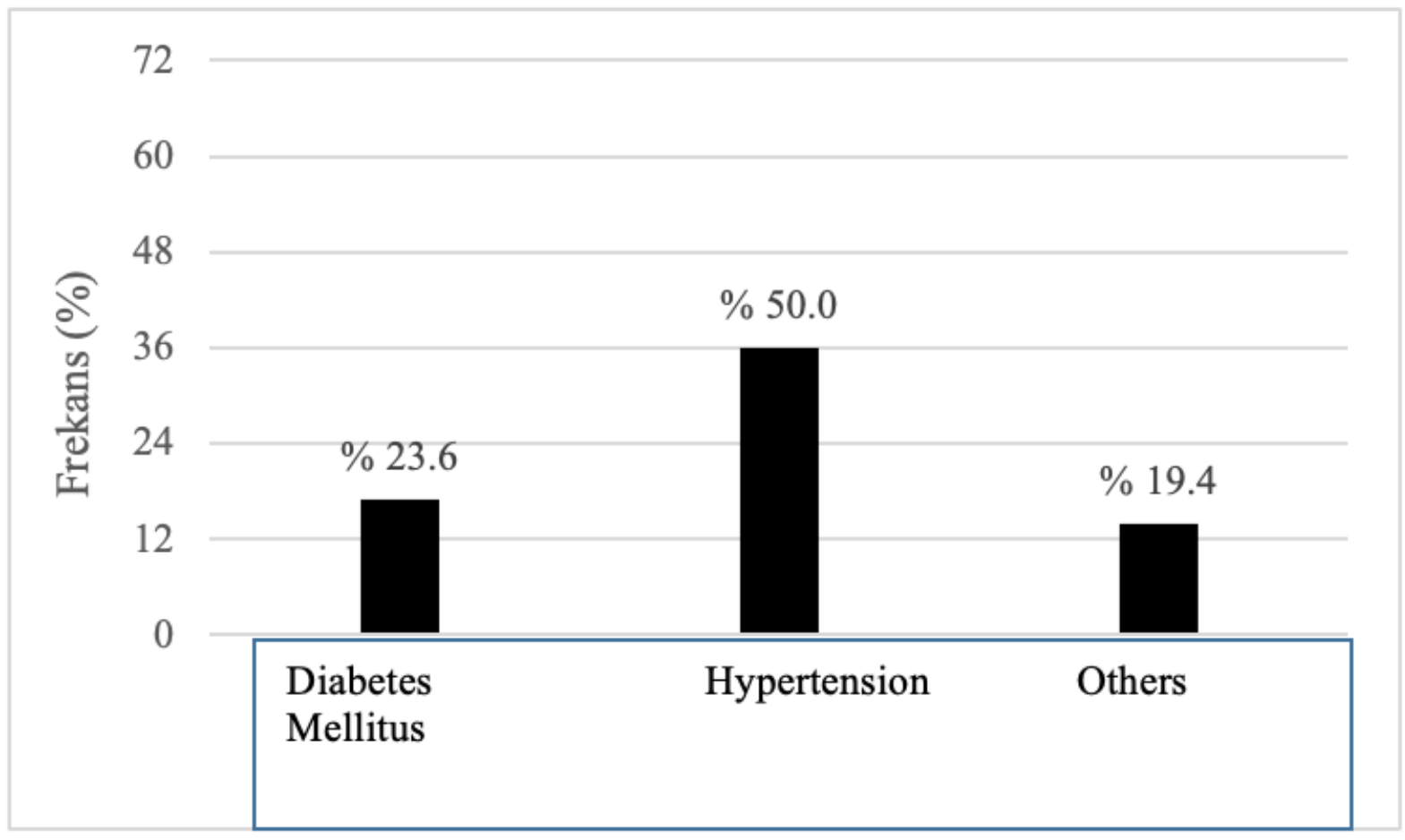

Figure 1

Distribution of additional chronic diseases in individuals receiving hemodialysis treatment

\section{Supplementary Files}

This is a list of supplementary files associated with this preprint. Click to download.

- supplement1.docx

- supplement2.docx 